\title{
Book Article Review: Defending and Creating Place Identities
}

\author{
Ar. Sayed Ahmed (Corresponding author) \\ Department of Architecture, Bangladesh University (on study leave) \\ 15/1 Iqbal road, Mohammadpur, Dhaka 1207, Bangladesh \\ Cell no:+8801707219556_E-mail: ar.sayedahmed@gmail.com
}

Received: August 22, 2020 Accepted: October 7, 2020 Published: October 18, 2020

doi:10.5296/ijch.v7i2.17721 URL: https://doi.org/10.5296/ijch.v7i2.17721

\begin{abstract}
The authors selected four neighborhoods in Melbourne. Two older suburbs, Camberwell and Fitzroy; were in threat from the new development challenges. Characters are something preexisted. Here dominant architectural styles with heritage value also regarded as important factor. On the other hand, two new housings like Beaconcove and Caroline Springs were modeled after imposed character. They tried to find place identities in residential developments. For that, front gardens of suburbs had been identical marketing agenda which created instinct character of space. To find out the real character of space, authors asked several questions to the inhabitants: how they react about mixed ethnicity, building code's impact over planning decisions and at which limit they might tolerate change for the sense of place? This review will try to find the place making extracts from the book 'Becoming spaces'.
\end{abstract}

Keywords: Space, Identity, Urban character, Power, Place making

\section{Introduction}

To create and preserve urban character is a global trend in capitalist world but also have some local immergence. Authors believe Melbourne got a streetscape based character. Such base is founded by the academy during the 1980's and it was introduced to planning practice during the 1990's. In this context, local councils took lead for characterization while market oriented developers and law offices gave the meaning of spaces where actual resident experiences were ignored. Urbanity in globalization era made people fundamental against any change over the character of places. The authors' derived an effective methodology which included politics, marketing, legislation and economic agreement; to judge three specific facts. Those are: residents' experiences, social discourses and urban morphology. The term 'character' was a 
sliding one as it oscillates between spatiality and sociality. Thus they urged us to evaluate them as emotional 'feel' attached to 'atmosphere' but with diverse dimensions.

\section{Methodology}

First of all, it was necessary to read the whole context carefully and segregate case studies into specific sorts. The authors conducted an extensive survey in all four cases including migrants and local residents. This gave a true picture of existing scenario to analyze and pick the results.

\section{Results}

First study area of this research was Comberwell neighborhood, a middle ring on a hill established in 1880 and $50 \%$ of the houses are of Victorian-Edwardian style. Mostly for upper middle class and it's expensive. Character could be defined by its walkability, front gardening, dense canopy tree and streetscape comprised of one or two storey elevation. Lack of ethnic diversity is evident as the inhabitants like to search for comfort zone: 'people like me'. Protest for redevelopment of railway station in 2003 demonstrated that change is not accepted. Their strong idea of uniformity could also be in threat. If crassness of money showoff by rich Chinese immigrants and running BMW or Mercedes Benz on streets, will be regarded as tasteless. Only neo-traditional buildings are appreciated for new construction. Authors described it as 'Procrustrian character': welcome but under renounced condition. Besides, increased crime was identified as big problem associated with immigrants' presence.

Second study area, Fitzroy was a mixed inner city suburb and oldest among all other examples, established in 1839. Specially started as row housing for the former factories and warehouses, it developed two sorts of characters, crime with poverty and creativity with graffiti, once regarded as graffiti capital of Australia. Ethnical diversity includes southern Europeans like Maltese and Greeks, Asians and African refugees. High-rises of public housing are considered as landmarks, added 'creative layers' along with built cottages on the lots over whole blocks. In 2002, a massive protest was made against proposed eight storey high rise. So, consistency and diversity- both constituted the social and spatial aspects to create its identity. Authors identified it as very 'edgy sense of difference'.

For old suburbs like Comberwell and Fitzroy, it is sure that place identity is supported by densification policies while quirky inhabitants and building typology derived the characters of space.

The third case study, Beaconcove was a former industrial site; modeled after garden city concept of 1990, during the period of radical deregulation. Thus density control was not considered here. The most phenomenal characters are Swallow Street with series of greens and two to three storey housing units. A redevelopment project was turned down during the 80's which is later proved as positive and market oriented aspect for the community. It is popular destination for Asian migrants; some are sustaining here up to three generations. This also raised the value and price of the rent. As a result, developers created such exaggerated environment that if anyone cannot adapt with, are leaving the suburb. So, here status is always secured by predetermined law. Nearly 600 housing units were erected, where darker colors were implemented at bottom part and upper parts were decorated with lighter colors. This color 
scheme was well merged with the green in front of the houses. The housing thus got a nick name of 'logo land'. Its initial style included neo-Georgian theme, then it followed neotraditional and now adapting contemporary trends also. It reflects conflicting desires for place identity and character. It has diverse residents compared to the other neighborhood of Melbourne.

The last case study, Caroline Springs, was comparatively new housing built by famous Delfin Corporation in 2000. It's a series of villages planned around shared open spaces where waterways and parks introduced the strong sense of place and community but a paradoxical character. Roads with entrance gateway are significant construct here and also a narrative to relate nature and history. Neighborhood pattern was segregated according to their status interestingly. Residents need to buy whole blocks and follow strict rules to shape the house with setbacks, fence heights, mandatory portico installation, etc. This is how enforced law and defined codes ensured uniformity in streetscape. Passion for period style houses are observed but not all inhabitants agreed with it as diversity of multicultural mixture is in practice. Again, such practice is not expressive over the facades. Authors believe that a mixture of 'commonality with differences' secured it against possible threats but also provided scope for change if needed in the future.

\section{Discussion}

After careful evaluation, Its found there are ten topics of contradiction in character discourse over these four case studies: Sense of security, comfort, nature, heritage, uniformity, streetscape, social status, immigration, property value and covenants. In new developments, cost and status are high and if street is seen as character of discourse, then such kind of housings are closed behind entry gates and confined in spatial structures. But those are also open socially in themselves. For example, Beaconcove, the area of the highest cost seems a club rather any society. For Camberwell, it is also area of high cost but it is not socially open rather closed to some social classes. The neighborhood also thinks that their uniformity is under threat which is comprised of history, modesty and taste. Property value and political activism are two major hindrances for any kind of change. On the other hand, both new suburbs like Beaconcove and Caroline Springs are criticized by its inhabitants. Uniformity here alleged well by the authors as 'Camouflage within differences'. Again, Fritzroy could be seen as moderate despite being old housing because it got graffiti heritage which led them to develop a creative and radically open society. It also wants to preserve low rent trend which created immigrant friendly society. Here uniformity depends on gentrification; juxtaposition and creativity. People do not want them in streetscape rather in the identical place and character as 'edgy sense for social differences'. Moreover, older housing areas like Camberwell and Fritzroy had decided character of the space as 'feel', an emotional state of acquired taste. But the newer suburbs like Beaconcove and Caroline Springs identified character of spaces as instant creation. Authors recommended the first two old suburb cases as 'surface acquiring depth' and second two new housing cases as 'depth inappropriate to surface'. They also concluded that characters could be defined in terms of urban codes and covenants. Planning code, law enforcement and city policies are the physical characters in selective form while interview of residents flourished tangible character in socio-political (resistant) form. A slippage between physical and social is 


\section{MIN Macrothink}

the only prevailing character.

\section{Conclusion}

To recapitulate, it could be inscribed distinctly that case studies of traditional neighborhood areas seem to be more alive because they have challenges, which can never be settled. But for new housings, it is prefixed and the natural social fragmentation is stopped, thus closed down the process of 'becoming' of places, also will not be easy for them in near future. Here, any developers decide ultimate place identities and promised the inhabitants not to change those by the dint of agreement and abiding laws. Unfortunately, this is still the prevailing trend in our capitalist era, but how long it will continue where fuel crisis, climate change and xenophobia are waiting ahead, is really a burning question for survival.

\section{References}

Dovey, K., Woodcock, I., \& Wood, S. (2010). Defending and creating place identities, Chapter 5: Slippery Characters. In K. Dovey (Ed.), Becoming Places: Urbanism/Architecture/Identity/Power (pp. 57-78). Routledge publisher. https://doi.org/10.4324/9780203875001

\section{Copyright Disclaimer}

Copyright reserved by the author(s).

This review article is an open-access article distributed under the terms and conditions of the Creative Commons Attribution license (http://creativecommons.org/licenses/by/3.0/). 